\title{
THE EFFECT OF A PROCESS APPROACH USING REPORT WRITING FRAME ON STUDENTS' WRITING ACHIEVEMENT
}

\author{
Khoiriyatul Hariro \\ E-mail: khoiriyatulhariro@yahoo.com \\ Universitas Islam Negeri Sunan Ampel Surabaya
}

\begin{abstract}
This study is aimed at investigating the effect of process approach using Report Writing Frame on students' writing achievement. The design of this study was quasi-experimental design. The subjects of this study were the third semester students of Academic Writing class of English Education Department of Brawijaya University of Malang. The result of t-test showed that the students who were taught using Report Writing Frame have better writing achievement than those who were taught without using Report Writing Frame. Besides, from the five categories or aspects which were scored; organization, content, grammar, vocabulary and mechanic, it indicated that the students who were taught using Report Writing Frame had more significant improvement in term organization, content and vocabulary.
\end{abstract}

Keywords: report writing frame, process approach, students' writing achievement

\section{INTRODUCTION}

Among the four skills that must have been mastered by students in learning foreign or second language, writing is the most difficult and complex skill. It is in line with Richards and Renandya (2002) who claim that there is no doubt that writing is the most difficult skill for L2 learners to master. The difficulty is not only in how to generate and organize the idea, but also how to make the text to be a readable text for the reader. Writers are demanded to express their ideas in written English appropriately. This opinion is also supported by Cahyono and Widiati (2011) who say that writing is often believed to be the most complex one compared to the other 
three skills, i.e, listening, speaking and reading. Before writing, students have to really understand what they are going to write and also they have to think about the way how to make readers can easily understand the message that they convey.

The organization of ideas, diction, grammar, and punctuation are the aspects to be considered by the writers to make a good readable writing product. Richards and Renandya (2002) state that L2 writers have to pay attention to higher level skills of planning and organizing as well as lower level skills of spelling, punctuation, word choice, and so on. Therefore, learners also have to pay attention to things related to mechanics such as the use of correct punctuation, spelling, and capitalization. Another complexity is writers have to learn how to combine words, phrases, clauses and sentences to be a coherent paragraph. Moreover, writers also have to learn how to reduce redundancy which can be influenced by the rhetorical tradition of their first language when they are writing. There are differences between the rhetorical conventions of English texts and L1 learners' texts. Therefore, learners often find it is difficult to adjust from their native text convention into English text convention. It is in line with Brown (2007) who says that writers must learn how to remove redundancy (which may not jibe with their first language rhetorical tradition), how to combine sentences, how to make references to other elements in a text, how to create syntactic and lexical variety, and much more.

There are two approaches that can be used in teaching writing. They are product approach and process approach. Cahyono and Widiati (2011) explain that in the light of writing as product, writing is considered to be the final product of writing activity. Therefore, in product approach, the emphasis is in the product of writing like the essay, the report, the story and what that the product should "look" like. Compositions were supposed to (a) meet certain standards of prescribed English rhetorical style, (b) reflect accurate grammar, and (c) be organized in conformity with what the audience would consider to be conventional. A good deal of attention was placed on "model" compositions that students should emulate and on how well a student's final product measured up against a list of criteria that included content, organization, vocabulary use, grammatical use, and 
mechanical considerations such as spelling and punctuation (Brown, 2007:391). From those explanations above, it can be said that writing as product not on focus on the product of writing but also focus on the "model" which can avoid the creativity of students as a writer.

Meanwhile, in process approach the emphasis is in the process of how to write the product of writing. The model of writing as process came into being later than writing as product, and it is considered to be the antithesis of the approach which over-emphasizes the end result of the process. Besides, in process approach, students are seen as creator of language, when they are allowed to focus on content and message, and when their own individual intrinsic motives are put at the center of learning (Brown, 2007). It means that students can be more creative in writing because they can write not only based on the "model" but also based on their own individual intrinsic motives. In writing as a process, the "model" is just become the example and/ or guideline for the students in writing. Then, students can create their writing based on their individual intrinsic motives.

In this research, the researcher views writing as a process approach as proposed by Seow in Richard and Renandya (2002) since it is simpler, clearer and easier to be understood and implemented which consists of four stages, namely planning, drafting, revising, and editing. Seow states that the writing process as a private activity may be broadly seen as comprising four main stages: planning, drafting, revising, and editing. Pre-writing is any activity in the classroom that encourages students to write. It stimulates thoughts for getting started. At the drafting stage, the writers are focused on the fluency of writing and are not preoccupied with grammatical accuracy or the neatness of the draft. When students revise, they review their texts on the basis of feedback. Revising is not merely checking for language errors. It is done to improve global content and the organization of ideas so that the writer's intent is made clearer to the reader. At this stage, students are engaged in tidying up their texts as they prepare the final draft for evaluation by the teacher.

Planning stage, as the first stage of writing process called prewriting stage, is an important stage because it is the basic stage in which students can make a plan of what they are going to write. Brown 
(2007) says "The prewriting stage encourages the generation of ideas." In pre-writing students are asked to outline their work before writing the draft. It is also very important stage for students to organize their ideas in writing and it will determine how interesting the text or essay they are going to write. It is in line with Wing (2009) that has an opinion that pre-writing is the most important part of the writing process as it lays a foundation for the writing that is to come. He also surely points out that optimal pre-writing strategies eliminate confusion and minimize writer's block while actually writing. Therefore, a mastery of pre-writing strategies is an invaluable investment that is a must for any serious, academic writer. There are some strategies which can be used in planning or pre-writing. They are, mind mapping, questioning, outlining, free writing, listing, brainstorming, clustering, using graphic organizer, reading a passage, skimming and scanning a passage, etc.

Report Writing Frame is one of some strategies that can be used in planning or pre-writing stage. It is the development of Graphic Organizer which is the combination of Graphic Organizer and writing report text. Merkley and Jeffries (2000) define graphic organizer as a visual stimuli for written and verbal communication. In other word, graphic organizer can be described as a visual stimulus for written and verbal communication that writers can organize ideas and concept into a visual format. It depicts a visual and organized display that makes information easier to understand.

Hartman (2002) categorizes graphic organizes into some formats which are concept maps, flowcharts, sequence chains, Venn diagrams and webs. While Broomley devides the types of graphic organizer into conceptual, hierarchical, cyclical and sequential. Below are the elaborations of graphic organizer adapted from Bromley et al. (1999) as cited in Shaffer (2007): (1) conceptual, this type of graphic organizers includes a main concept or a central idea with supporting facts, evidences, or characteristics. It helps students to show their knowledge of a central idea. (2) hierarchical, this type of graphic organizers begin with a topic or concept and then include a number of ranks or levels below the topic and it is used when students need to break down broad concept into sub concept, (3) cyclical, it depicts a 
series of events without beginning or end. The formation is circular and continuous, and (4) sequential, it arranges events in chronological order. It is helpful when events have a specific beginning an end. It is also appropriate for cause and effect and problem-solving text. In this research, the researcher uses hierarchical format of graphic organizer in the form of "Report Writing Frame".

Bromley, Devitis, and Modlo (1995) define that graphic organizer as visual representation of knowledge which provides structure for information, a way of structuring information, of arranging information aspects of a concept or topic into pattern." Therefore, in term of organization, using graphic organizer can help writers to generate their ideas and to write their texts or essays to be more organized and more systematically.

Another advantage of graphic organizer is it can also be used as a conceptual communicative tool (Katayama \& Robinson, 2000; Merkley \& Jeffries, 2000). It is a tool to make writers see their thought or ideas easily in visual format. Therefore writers can easily see what to improve, add or omit to make a good writing product. It helps writers to elaborate the content of what they are going to display in the form of writing. Moreover, it also facilitates writers to give more attention in the language use of writing like grammar, vocabulary and mechanics.

In addition, graphic organizer facilitates the integration of longterm memory and new learning for adult learners. Adult learners generally have more background knowledge, and graphic organizer bridge what adult learners already know with what they are learning. Graphic organizer actually triggers long term memory and promotes synthesis with new information (Materna, 1997 as quoted by Mcknight, 2010).

There are several previous studies both in foreign language context and also in native language context that proposed some theories and conclusion regarding the use of graphic organizer in teaching and learning process. The first one is a Classroom Action Research (CAR) which was conducted by Yavani (2013) who tried to solve the writing problem of the writing class of Elementary 4 level at Lembaga Bahasa dan Pendidikan Professional (LBPP) LIA Malang through the 
implementation of graphic organizer in writing persuasive article. The subjects of the research are the twenty people of adult learners whose age are between 20 to 30 years old who study English Writing in level Elementary 4. They are in the level of Elementary 4 in which it is the highest level of other levels of writing class in LBPP LIA Malang. The findings of this study showed that using graphic organizer in process writing could beef up students writing ability, particularly in writing persuasive articles. Besides, the students' active involvement are also increased in writing class as well as students' positive perceptions towards the implementation of graphic organizer.

Another study is conducted by Lestari (2012) who implemented graphic organizer in teaching writing argumentative essay. It is also Classroom Action Research (CAR) in which the subjects of the research are the students of Writing III class of English Education Department of IAIN Sunan Ampel Surabaya. The result of her research shows that graphic organizer is helpful for students to improve students' writing performance, especially in term of organization, content vocabulary. It also can increase the motivation of the students in writing argumentative essay.

In native language context, Barnett (2007) concludes that using graphic organizer within reading/writing and social studies lessons is an effective way to enhance comprehension. The study showed significant improvement to almost all of the students over a 3-week period when graphic organizer was used in reading and writing. It shows that graphic organizer is useful thinking tool that allow students to organize information and allow them to see their thinking concept.

Moreover, a study conducted by The Institute for the Advancement of Research in Education (IARE, 2003) shows that using graphic organizer in teaching and learning has some benefits. It shows that graphic organizer helps students in the following aspects: (1) it helps students to brainstorm ideas, (2) it develops, organizes, and communicates ideas, (3) it can make students easily see connections, patterns and relationship of ideas, (4) it asses and share prior knowledge, (5), it helps students to develop their vocabulary, (6) it helps students in making outline and highlight important ideas, (7) it classifies or categorizes concepts, ideas, and information, (8) it helps in 
comprehending events in a story or book, (9) it improves social interaction between students, and facilitate group work and collaboration among peers, (10) it guides review and study, (11) it improves reading comprehension skill and strategies, (12) the use of graphic organizer in reading and writing is giving students facilitate recall and retention.

From the explanation of those theories and researches related the advantages of using graphic organizer which have been explained above, it can be concluded that the use of graphic organizers can help writer to write a text or an essay in term of organization, content, vocabulary, grammar and mechanic. Regarding to the advantages of graphic organizers above, the researcher will conduct experimental research using graphic organizer in the form of "Report Writing Frame" to know the effect of "Report Writing Frame" in increasing students' writing achievement of English Education Department of Brawijaya University students in writing information report text. Information report text is used because, based on the course outline of English Education Department of Brawijaya University, it is one of the text types which has to be learned by students at the third semester.

According to Anderson and Anderson (2003), an information report is a piece of text that presents information about a subject. Its purpose is to classify and/ or describe using facts about the subjects' parts, behaviour and qualities. The subject is usually general rather than particular, for example 'skin' rather than an individual person's skin. Furthermore, Anderson and Anderson (2003) state that the generic structure of information report are: (1) a general opening statement that introduce the subject of the report. It can include a short description and a definition, (2) a series of paragraphs about the subject. It is usually a new paragraph describe one feature of the subject and begins with a topic (or preview) sentence, (3) a conclusion that summaries the information presented and signals the end of the report. The language features usually found in an information report are: (1) technical language related to the subject, (2) generalised term, and (3) use of timeless present tense.

This study is aimed at investigating the effect of process approach using Report Writing Frame on students' writing 
achievement. It was hypothesized that the students who were taught using Report Writing Frame have better writing achievement than those who were taught without using Report Writing Frame. The subjects of the research in this study were the third semester students of undergraduate program in English Education Department of Brawijaya University, Malang, East Java.

\section{METHOD}

This study employed quasi-experimental research since the researcher had no access to randomize the classes. Randomizing the classes had been determined by the institution of the English Education Department of Brawijaya University. When the research can only assign randomly different treatments to two different classes, the researcher uses quasi-experimental research design (Charles, C.M. as quoted by Latief, 2013). The two classes which are not determined by the researcher used for this experimental study. The researcher conducted randomly assignment by assigning the two classes. One class assigned as the experimental group and another one as the control group.

This research was conducted in four meetings. These four meetings were conducted based on the class schedule. The first meeting was used for the introduction of the materials and also for the pretest both in the experimental and control group. The second meeting and the third meeting used to teach writing based on the writing process proposed by Soew (2002) which consist of planning, drafting, revising and editing stage. For the experimental group, the researcher gave the treatment by using Report Writing Frame in planning stage. Meanwhile, for the control group, the researcher conducted the research without using Report Writing Frame (using freewriting) in the planning stage. The last meeting is used for the posttest both in the experimental and control group.

There was only one instrument in this research. It was writing test. There were two kinds of test which were used in this research, the pretest and posttest. The pre-test was administered at the first meeting and post-test was administered at the last meeting to the both groups, experimental and control group. In the pretest and posttest, 
the students of both classes wrote an Information Report text based on the most familiar topic that they had chosen before and the subtopic that had been determined by the lecturer. The topics in pretest and posttest were different but equivalent. The result of students' pretest was used to measure the students' initial mastery before the treatment and to make sure that the two groups were statistically equal or not. For the post test, the students in experimental group wrote an Information Report text using Report Writing Frame and the students in control group wrote an Information Report text without using Report Writing Frame.

\section{FINDINGS AND DISCUSSION}

The pretest was followed by 20 students in the experimental group and 20 students in the control group. It was conducted at the same time, $09.40-12.10$ on Wednesday, October 22, 2014 for the experimental group and on Thursday, October 23, 2014 for the control group. Table 1 presents the summary of the pretest scores.

Table 1 Summary of the Pretest Scores

\begin{tabular}{lll}
\hline & Experimental Group & Control Group \\
\hline $\begin{array}{l}\text { Number of students } \\
\text { Highest score }\end{array}$ & 20 & 20 \\
$\begin{array}{l}\text { Frequency of the highest } \\
\text { score }\end{array}$ & 1 & 85 \\
Lowest score & 45 & 2 \\
$\begin{array}{l}\text { Frequency of the lowest } \\
\text { score }\end{array}$ & 2 & 50 \\
Mean score & 62.88 & 1 \\
Standard deviation & 11.305 & 63.50 \\
\hline
\end{tabular}

Based on the table above, the mean score of the experimental goup on the pretest was 62.88 , while the the mean score of the control group was 63.50 .

The posttest was followed by 20 students in the experimental group and 20 students in the control group. It was conducted at the same time, $09.40-12.10$ on Wednesday, November 5, 2014 for the 
experimental group and on Thursday, November 6, 2014 for the control group. Table 2 presents the summary of the posttest scores.

Table 2 Summary of the Posttest Scores

\begin{tabular}{lll}
\hline & Experimental Group & Control Group \\
\hline $\begin{array}{l}\text { Number of students } \\
\text { Highest score }\end{array}$ & 20 & 20 \\
Frequency of the highest & 45 & 85 \\
score & & 1 \\
Lowest score & 50 & 50 \\
$\begin{array}{l}\text { Frequency of the lowest } \\
\text { score }\end{array}$ & 1 & 2 \\
Mean score & 80.75 & 66.00 \\
Standard deviation & 12.033 & 11.309 \\
\hline
\end{tabular}

The result of the posttest showed that the mean score of the experimental group, which the students who were taught using Report Writing Frame, was higher than the control group, which the students who were taught without using Report Writing Frame. Based on the table above, the highest score of the experimental group was 95 and the frequency of the highest score was 4 . While, the lowest score of the experimental group was 50 and the frequency of the lowest score was 1 . In On the other hand, the highest score of the control group was 85 and the frequency of the highest score was 1 . While, the lowest score of the control group was 50 and the frequency of the lowest score was 2.

The mean score of the experimental goup on the posttest was 80.75, while the mean score of the control group was 66.00. The mean difference between control and experiment group for posttest was 14.75 point. Yet, to make it clear, the difference between the two groups should be computed by using t-test that will be addressed in the following part respectively. 


\section{The Result of the Fulfillment of Statistical Assumption}

Test of assumption conducted to determine the statistical analysis used in testing research hypothesis. Thus, test of normality and homogeneity were needed to be conducted to fulfill the assumption.

Normality testing was used to determine whether the data is normally distributed or not. In this research, test of normality were employed through Kolmogorov-Smirnov by using SPSS 20.0 which is shown in following table:

Table 3 Kolmogorov-smirnov Test for Normality Assumption

\begin{tabular}{lllll}
\hline & $\begin{array}{l}\text { Pretest } \\
\text { EG }\end{array}$ & $\begin{array}{l}\text { Posttest } \\
\text { EG }\end{array}$ & $\begin{array}{l}\text { Pretest } \\
\text { CG }\end{array}$ & $\begin{array}{l}\text { Posttest } \\
\text { CG }\end{array}$ \\
\hline $\begin{array}{l}\text { Kolmogorov-smirnov } \\
\text { Z }\end{array}$ & 1.008 & .744 & 1.083 & .612 \\
\hline Asymp. Sig (2-tailed) & .261 & .637 & .192 & .847 \\
\hline
\end{tabular}

The normality can be decided by looking at the $\mathrm{Z}$ value and also the significance value. Based on the data for normality assumption, the $\mathrm{Z}$ value for pretest of the experimental group was 1.008 which significance value was .261 and the $Z$ value for pretest of the control group was 1.083 which significance value was .192. Meanwhile, the $Z$ value for posttest of the experimental group was .744 which significance value was .637 and the $\mathrm{Z}$ value for posttest of the control group was .612 which significance value was .847 . Based on the data above, all variables $\mathrm{Z}$ value was lower than 1.96 of $\mathrm{Z}$ table and the significance value was higher than the alpha (.05), thus the Ho was rejected. In other words, the data followed normal dispersion and normality assumption was fulfilled.

The second statistical assumption that should be fulfilled was homogeneity testing. The assumption of homogeneity is that the variability in scores on one variable is roughly the same at all values of other variables (Tabachnik and Fidell, 1983: 86). To estimate the homogeneity, the data gained from the pretest of the both groups computed by using SPSS 20.0. 
Table 4 Lavene's Test for Homogeneity of Variance

\begin{tabular}{llll}
\hline Lavene's statistics & Df1 & Df2 & Sig. \\
\hline .042 & 1 & 38 & .838 \\
\hline
\end{tabular}

Based on the Table 3.6, the significance level for the Lavene's test was .838. Since the significance level that used by the researcher was .05 (95\% confidence), thus the observed significance level for the Lavene's test was higher than the level of confidence used in this study. Therefore, the Ho was rejected. Moreover, both groups' variances were equal, and then the homogeneity assumption was fulfilled.

\section{Data Analysis}

This part was intended to answer the research question whether the Report Writing Frame has any effect or not on students' writing achievement by comparing the posttest result of both groups, experimental group and control group. The data analysis used in this research was based on the fulfillment of the analysis assumptions, normality and homogeneity. However, the result showed that both data were in normal distribution and homogenous. Therefore, parametric statistics, independent $t$-test was used to analyze the data. Table 5 shows the result of the independent $t$-test.

Table 5 The t-test Result of the Students' Posttest in the Experimental and Control Groups

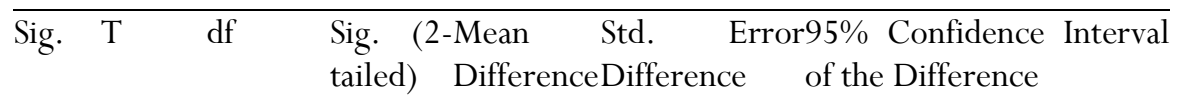

\begin{tabular}{rrrrrrrr}
\cline { 5 - 6 } & & & & & Lower & Upper \\
\hline 709 & 3.995 & 38 & .000 & 14.750 & 3.639 & 7.275 & 22.225 \\
& 3.995 & 37.854 & .000 & 14.750 & 3.639 & 7.274 & 22.226 \\
\hline
\end{tabular}

By using the t-test analysis, the difference between the two means was computed. If the Sig. (2-tailed) value is less than or equal to .05. It means that there is a statistically significant difference between the two conditions. According to the result of the posttest illustrated 
in Table 3.7, the $\mathrm{P}$ value is .000 and it is less than .05. This smaller $\mathrm{P}$ value shows strong evidence to reject Ho. It means that Ho is rejected and H1 is accepted. It implies that Report Writing Frame has positive effect on student's writing achievement. The result shows that the treatment was effective to make an important difference between the experimental group and the control group.

Based on the research findings, it was found that the mean score of the experimental group was 62.88 and the mean score of the control group was 63.50 in the pretest. Meanwhile, the the mean score of the experimental group was 80.75 and the mean score of the control group was 66.00 in the posttest. Thus, the mean difference between the experimental group and control group was 14.75 point. Therefore, there was a significant difference between the mean score in the experimental group and the control group to reject the null hypothesis. Based on the difference of the mean score of the experimental group and the control group above, it meant that the students who were taught using Report Writing Frame have better writing achievement than those who were taught without using Report Writing Frame (using freewriting).

It is clear that the Report Writing Frame had effect in improving students' writing achievement in the experimental group. The difference between the two group performance in writing Information Report text suggested a strong possibly that the students who were taught using Report Writing Frame have better writing achievement than those who were taught without using Report Writing Frame. This fact is supported by the result of the statistical computation by using t-test that showed there was any difference between the students who were taught using Report Writing Frame and those who were taught without using Report Writing Frame (using freewriting).

From the five categories which were scored; organization, content, grammar, vocabulary and mechanic, it indicated that the students who were taught using Report Writing Frame had more significant improvement in term organization, content and vocabulary. It was proven by the findings of the students' score that showed there were some differences of the students' improvement percentage of 
each category of the posttest in experimental group. From the 20 students in experimental group of the posttest, there were $75 \%$ students who did the improvement in term of organization according to rater 1 and $85 \%$ according to rater 2 . For the content, there were $75 \%$ students who did the improvement according to rater 1 and $85 \%$ who did the improvement according to rater 2 . There were only $40 \%$ students who did the improvement in term of grammar according to rater 1 and only $45 \%$ according to rater 2 . For the vocabulary, there were $60 \%$ students who did the improvement according to rater 1 and $65 \%$ students who did the improvement according to rater 2 . The last one, there were only $35 \%$ students who did the improvement in term of mechanic according to rater 1 and $40 \%$ students who did the improvement in term of mechanic according to rater 2.

\section{CONCLUSIONS AND SUGGESTIONS}

This research investigated the students' writing achievement in writing Information Report text between the students who were taught using Report Writing Frame and the students who were taught without using Report Writing Frame (using freewriting). The results were analyzed statistically and interpreted logically by considering some previous research. In accordance with the research problem and the result of data analysis, it can be concluded that the students who were taught using Report Writing Frame have better writing achievement than those who were taught without using Report Writing Frame. Besides, from the five categories or aspects which were scored; organization, content, grammar, vocabulary and mechanic, it indicated that the students who were taught using Report Writing Frame had more significant improvement in term organization, content and vocabulary.

Based on the data analysis and the discussion in the previous chapter, the result of this research provides theoretical and practical contributions toward teaching writing of Information Report text for students of undergraduate program of education. For the theoretical contribution, the result of this research supports the existing theory on the application of graphic organizer in the form of Report Writing 
Frame as a technique or strategy in teaching writing Information Report text for students of undergraduate program. Besides, the result of this study is also considered to be a consideration for English lecturers of undergraduate program to adopt or adapt this strategy and deliver it to their students in teaching writing Information Report text. Practically, the English lecturers of undergraduate program can improve their teaching strategy by implementing Report Writing Frame in teaching writing Information Report text.

Based on the conclusion, it is known that from the five categories or aspects which were scored; organization, content, grammar, vocabulary and mechanic, it showed that the aspect of grammar and mechanic were still low of improvement. Therefore, the researcher suggested to the further researchers to adapt this technique or strategy in teaching writing of Information Report text for undergraduate students in order to it can also improve significantly those two aspects which are still low. Moreover, it is also suggested to the further researcher to know the students' opinion of the use of Report Writing Frame in teaching writing by distributing the questionnaire to the students in order to the researcher can know the students' difficulties in writing Information Report text using Report Writing Frame.

\section{REFERENCES}

Anderson, M. and Anderson, K. 2003. Text Types in English 2. South Yarra: Macmillan Education Australia Pty Ltd.

Anderson, M. and Anderson, K. 2003. Text Types in English 3. South Yarra: Macmillan Education Australia Pty Ltd.

Barnet, K.P. 2007. Graphic Organizers' Effectiveness in Teaching Comprehension in Reading and Social Studies. Alabama. Accessed on $17^{\text {th }}$ November, 2013 from www.the university of alabama.html.

Broomley, K., Devitis, L., Modlo, M. 1995. Graphic organizers: Visual Strategies for Active Learning. Now York: Scholastic Professional Books. 
Brown, H. D. 2007. Teaching by Principles: an Interactive Approach to Language Pedagogy ( $3^{\text {rd }}$ ed). New York: Pearson Education, Inc.

Cahyono, B.Y. and Widiati, U. 2011. The Teaching of English as a Foreign Language in Indonesia. Malang: State University of Malang Press.

Hartman. 2002. Graphic Organizers as a Teaching Strategy. City College of New York. Accessed on October 15 $5^{\text {th }}, 2013$ from http: /www.awresrchpprpage.htm.

Katayama, Andrew, D. and Robinson, D.H. 2000. Getting Students 'Partially' Involved in Note-Taking Using Graphic Organizers. Journal of Experimental Education68 (2) 119.retrived on November $18^{\text {th }}, 2013$ from www.heldref.org.

Latief, M.A. 2013. Research Methods on Language Learning an Introduction. Malang: State University of Malang Press.

Lestari, S.A. 2012. The Implementation of Graphic Organizer in Teaching Argumentative Essay of the Fourth Semester Students of English Education Department of IAIN Sunan Ampel Surabaya. S-2 Unpublished Thesis. Surabaya: State University of Surabaya.

Mckinght, K. 2010. The Teacher's Big Book of Graphic Organizer. San Fransisco: Jossey-Bass.

Merkley, D.M. and Jeffries, D. 2000. Guidelines for Implementing a Graphic Organizer. Reading Teacher 54 (4): 350-357.

Richards, J.C. and Renandya, W.A. 2002. Methodology in Language Teaching: an Anthology of Current Practice. Cambridge: Cambridge University Press.

Soew, A. 2002. The Writing Process and Process Writing. In J.C. Richard and Renandya, W.A. Methodology in Language Teaching: an Anthology of Current Practice. Cambridge University Press.

Yavani, Z. 2013. Improving Students' Writing Skill through Graphic Organizer in Process Writing at LBPP LIA Malang. S-2 Unpublished Thesis. Malang: State University of Malang. 
